example of a psychiatrist who combined both approaches quite naturally. He was a man of wide culture who loved books, music and theatre. One of his favourite authors was the American Saul Bellow whom he was fond of quoting. His favourite quotation was 'Life - I work at it and show steady improvement. I expect to be in great shape on my deathbed'.

He died on 29 July 2011. His wife, Margaret, predeceased him by 2 years. He is survived by his three sons - Andrew, a professor of otolaryngology, Christopher, a psychotherapist and Peter, a biological scientist.

Ben Steinberg

This obituary was originally published in the BMJ (BMJ 2011; 343: d6739)

doi: 10.1192/pb.bp.112.039826

\section{Dr Hanna Segal}

\section{Formerly President of the British Psychoanalytical Society and Vice-President of the International Psychoanalytical Association}

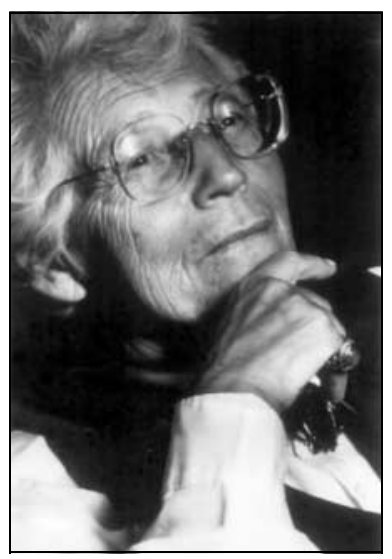

Hanna Segal, who died aged 93 in July 2011 in London, where she lived and worked since the end of the Second World War, had an inter-national reputation both as a psychoanalyst who developed psychoanalytic theory and for her contributions to art and creativity as well as politics and literature. In a psychoanalytic career of over 60 years, Segal was a leading exponent of the work of Melanie Klein, making it widely accessible. Segal was internationally sought as a clinician and teacher for her original and imaginative

understanding, in the tradition of Freud, of the unconscious phantasies governing the inner struggle between the forces that strive towards life and development and those that work towards destruction.

She was born Hanna Poznańska into a highly cultured Jewish family in Łódź, Poland, where her father was a barrister and an art critic fluent in many languages and with a deep interest in literature. Her mother showed huge strength and resourcefulness as the family struggled through the difficult experiences of the German occupation of Poland and France. Hanna was deeply attached to her older sister who died at the age of 4 from scarlet fever. When she was 12 , the family moved to Geneva where her father became editor of one of the publications of the League of Nations.

Although a student at the International School in Geneva, Hanna remained attached to her Polish roots and persuaded her parents to let her return to Warsaw at the age of 16 to complete her education. By her late teens she had read all the Freud that had been translated into Polish and had become interested in becoming a psychoanalyst herself. She was intellectually influenced by her wide reading that included Voltaire, Rousseau, Montaigne, Schopenhauer, Nietzsche, Proust and Pascal. The rise in Fascism led to her family being expelled from Switzerland, becoming stateless and impoverished and, having to interrupt her medical studies begun in Warsaw, in 1939 Hannah joined the family in Paris, where they had taken up residence. Segal's personal experience of poverty and lack of political freedom led her to join the Polish Socialist Party and her parents had to restrain her from joining the republican fighters in Spain. Her political commitment to the left, however, remained with her for the rest of her life. Like many Polish émigrés at the time of the German occupation of Poland, she fought to return to Warsaw and very nearly succeeded. She remarked somewhat ruefully later in her life that none of her friends who did make that return survived the war. As the Germans occupied Paris in 1940 the family fled again, this time across France, and only just managed to get to England.

Segal completed her medical studies in 1943 in Edinburgh where she met the psychoanalyst W.R.D. Fairbairn, which further determined the future course of her life. Fairbairn told her how she could train to be a psychoanalyst in London. She made the move to London, where she worked in psychiatry, playing a major part in the rehabilitation of mentally ill Polish soldiers, many of them in Long Grove Hospital. She was accepted for training in the British Psychoanalytical Society (BPS), entering into analysis with Melanie Klein and qualifying in 1945 at the age of 27. At 29, she married the mathematician Paul Segal, conceived their first son and presented her first paper, 'A psychoanalytic contribution to aesthetics', to the BPS. This famous paper puts the capacity to mourn at the centre of both the artist's work and the aesthetic response of the audience. Her imaginative idea that the substance of artistic creativity and aesthetic appreciation derive from the very psychic struggle itself, intrinsic to mourning loss and making reparation, is perhaps the most original attempt at a psychoanalytic understanding of creativity.

Soon after, Segal also trained as a child analyst, supervised by Paula Heimann, Esther Bick and Klein herself, and began teaching students of the BPS. In 1952, she became a training analyst and her analysands included candidates of the BPS, patients with psychosis and artists who came to her for help when their creativity became blocked. With her first book, Introduction to The Work of Melanie Klein (1964), she brought Melanie Klein's work to life in such an accessible way, using illustrations from her own clinical work, that it remains a standard text to the present day. Her second book, Klein (1969), in the Fontana Modern Masters series, demonstrated how Klein built on the ideas of Freud and extended them.

In this very fertile period Segal worked in collaboration with Herbert Rosenfeld and Wilfred Bion with patients with psychosis, including the analysis of those with schizophrenia, and wrote her seminal paper on symbolism, 'Notes on symbol formation'. Her distinction between more primitive and developed forms of symbol formation brought a clarification to the understanding of the genesis of disturbed states of mind. Many of the papers of this period were reprinted in her third book, The Work of Hanna Segal (1981), whereas her fourth book, Dream, Phantasy and Art (1991), proceeds via the interpretation 
of dreams to a deeper understanding of phantasy and symbolism.

Segal believed that the psychoanalytic understanding of the pervasiveness of destructiveness and denial could contribute significantly to the discussion of sociopolitical questions. Building on her lifelong passion for politics, Segal was one of the prime movers in the formation of a psychoanalytic movement against nuclear armaments. Her paper, 'Silence is the real crime', is one of the most important psychoanalytic contributions to the nuclear debate. The cross-fertilisation of Segal's interest in clinical disturbance of the functioning of the mind with artistic and aesthetic endeavour and human destructiveness made her an inspiring teacher and writer. Her later papers are drawn together in two more books, Psychoanalysis, Literature and War (1997), in which her paper 'The clinical usefulness of the concept of the death instinct' was reprinted, and Yesterday, Today and Tomorrow (2010). Segal loved reading both literature and detective stories and she wrote papers about novels by Joseph Conrad, Patrick White and William Golding, whose work she admired. She was particularly interested in Conrad who, like her, was by birth a Pole who adopted English and found that it offered him the greatest depth of expression of any language.

Segal was president of the BPS from 1977 to 1980, twice vice-president of the International Psychoanalytical Association, visiting professor at University College London in 1987/1988 and received the Mary Sigourney award for contributions to psychoanalysis in 1992. She was passionate about psychoanalysis and outspoken about her beliefs. In clinical supervision she was passionate about the plight of the patient and straightforward about the limitations of the analyst, while being scrupulously fair to both. In her interview for BBC Radio 4 Desert Island Discs in 2006, celebrating the 150th anniversary of Freud's birth, she said of the nature $v$. nurture debate that only in the most severe mental illness was nature the overwhelming factor. Segal was equally passionate about her family who loved her deeply. She was pre-deceased by her husband Paul Segal in 1996, and leaves three sons, four grandchildren and three great-grandchildren.

Bernard Roberts

doi: $10.1192 /$ pb.bp.112.039412

\section{Review}

\section{Teaching Psychiatry to Undergraduates}

Tom Brown \& John Eagles

RCPsych Publications, 2011, £35.00, pb, 336 pp. ISBN 9781904671992

Students' experience of psychiatry at medical school will influence not only their choice of career but also their lifelong attitudes to people with mental health problems, whatever their specialty. So, as psychiatrists, our responsibility for teaching psychiatry to undergraduates is great.

In his foreword, Professor Robert Howard paints a bleak picture of psychiatry teaching, with chaotic clinical placements and reluctant teachers. This has certainly not been our experience and we find many psychiatrists who are keen to teach and passionate about their specialty. Often, though, they do not know where to begin and become disheartened when they receive poor student feedback. Teaching Psychiatry to Undergraduates has something for all of them. It lies between a pocket guide and a reference book; it is invitingly light without skimping on its scope, and does not assume any prior knowledge of educational methods. The introductory chapters cover basic principles and recent developments in medical education, setting the scene by giving a broad understanding of the direction of travel. Those who just want to get on with preparing a teaching session can skip straight to some good chapters on how to give a lecture, do small-group teaching or problem-based learning, with an excellent chapter on the use of computers in teaching and how to create e-learning resources. This is an excellent book for dipping into: each bite-sized chapter is a good mixture of theory and reflection.

The chapters on time-efficient clinical teaching, use of simulated patients and role-play are good value, with tips for teaching in busy clinical settings. It is also refreshing to see chapters focusing on involvement of trainees and service users in teaching; the chapter on dealing with students in difficulty is especially worth reading.

The book is ambitious in its range and not all of the chapters will be relevant to everyone: for example, most teachers do not have control over organisation and funding of teaching. However, for a busy doctor who has not the time or motivation to read the chapters in full, they all include a concise summary giving an overview of the topic.

The authors have succeeded in producing a substantial reference book on teaching psychiatry that at the same time is easily digestible and small enough to carry around in a bag, allowing readers to use every possible opportunity to teach psychiatry as it should be taught to our students.

Ania Korszun Professor of Psychiatry and Education, Centre for Psychiatry, Wolfson Institute of Preventive Medicine, Barts and The London School of Medicine, email: a.korszun@qmul.ac.uk; Caroline Methuen Consultant Psychiatrist, Primary Care Liaison, and Honorary Senior Lecturer, Medical Education in Psychiatry, East London NHS Foundation Trust, City and Hackney Adult Mental Health Service.

doi: 10.1192/pb.bp.111.035501 